\title{
Local values and decisions: views and constraints for riparian management in western Mexico
}

\author{
A.C. Flores-Díaz ${ }^{(1),(2), \star}$, A. Castillo(2), M. Sánchez-Matías ${ }^{(2)}$, M. Maass ${ }^{(2)}$
}

Received November 29, 2013

Revised February 1, 2014

Accepted April 7, 2014

\section{ABSTRACT}

Key-words: fluvial systems, local knowledge, riparia, social-ecological systems, watersheds
Human decisions on ecosystems at the local level are based significantly on the institutional context but also on how people understand and value the place where they live. Located at the land-water interface and connecting the streams with their valleys, riparian areas provide relevant services to society on regional and global scales and are important to the people directly interacting with them. Using a qualitative research approach, we documented rural people's knowledge and values regarding the riparian system, as well as the agreements made on its management. We found positive values; a good understanding of the riparian system's dynamics and local arrangements for its management. Degradation was also observed, indicating a discrepancy between peoples' views and their practices. Ignorance of the national ordinances emerged as an important problem, also having consequences on the conservation of the riparian area. There are constraints between individual and collective decisions since benefits from good management are not necessarily reflected at the site, but on wider spatial-temporal scales. It is proposed (1) to consider the whole stream-riparia-parcel as a more realistic approach to assess and guide the riparian system's role; and (2) a co-production of knowledge between local people and scientists, promoting a co-responsibility stewardship of the basin-level management.

\section{RÉSUMÉ}

Valeurs et décisions locales : vues et contraintes pour la gestion des zones rivulaires dans l'ouest du Mexique

\author{
Mots-clés: \\ système fluvial, \\ connaissances \\ locales, \\ rivulaire, \\ système \\ socio- \\ écologique, \\ bassin versant
}

Les décisions humaines sur les écosystèmes au niveau local sont basées surtout sur le contexte institutionnel, mais aussi sur la façon dont les gens comprennent et apprécient l'endroit où ils vivent. Situées à l'interface terre-eau et connectant les ruisseaux avec leurs vallées, les zones rivulaires fournissent des services importants pour la société à l'échelle régionale et mondiale, mais surtout pour les personnes qui interagissent directement avec elles. En utilisant une approche de recherche qualitative, nous avons documenté les connaissances et les valeurs des populations rurales en ce qui concerne le système rivulaire, ainsi que les accords conclus sur sa gestion. Nous avons trouvé des valeurs positives; une bonne compréhension de la dynamique du système rivulaire et des arrangements

(1) Ecology and Natural Resources Management Program. Instituto de Ecología, A. C. Carretera Antigua a Coatepec 351. El Haya, Xalapa 91070, Veracruz, México

(2) Center of Ecosystem Research. Universidad Nacional Autónoma de México. Apartado Postal 27-3 (Santa María de Guido), Morelia, Michoacán. Antigua Carretera a Pátzcuaro 8701, Col. Ex Hacienda de San José de la Huerta 58190, Morelia, Michoacán, México

* Corresponding author: aflores@cieco.unam.mx 
locaux pour sa gestion. La dégradation a également été observée, indiquant une différence entre les points de vue des personnes et leurs pratiques. L'ignorance des règlements nationaux est apparue comme un problème important, ayant également des conséquences sur la conservation de la zone rivulaire. II y a des contraintes entre les décisions individuelles et collectives, puisque les prestations de bonne gestion ne se répercutent pas nécessairement sur le site, mais à des échelles spatio-temporelles plus larges. II est proposé (1) d'examiner l'ensemble rivière-rive-parcelle comme une approche plus réaliste pour évaluer et gérer la fonction du système rivulaire; et (2) une co-production de connaissances entre les personnes locales et les scientifiques, promouvant une gouvernance coresponsable de la gestion au niveau du bassin.

\section{INTRODUCTION}

Ecosystem management is a critical issue involving both nature conservation and human wellbeing. Ecosystem management encompasses a discussion mainly about decision-making on different scales and made by different social actors (Christensen et al., 1996; Carpenter et al., 2009), which requires our "better understanding of the ecological processes as well as the social interactions and cooperation rules" in order to drive sustainable decisions for human well-being (Maass et al., 2005). Studies on ecosystem management recognize that it is important to incorporate human values in ecosystems as a critical factor to achieve sustainability goals (Grumbine, 1994). From diverse disciplines there is recognition that "humans not only construct and manage landscapes, they also look at them, and they make decisions based upon what they see (and know, and feel)" (Nassauer, 1995, p. 230). Values and perceptions of landscapes and places are essential components for decision-making on a territory.

Natural processes occur there, where peoples' daily life takes place. In particular, rural people are making everyday decisions on lands and waters strongly tied to their livelihoods. Land production and water use by rural inhabitants are based on natural processes, recognized by scientists at present as ecosystem services and defined as goods and services people obtain from ecosystems (Daily, 1997; MA, 2003). Human benefits provided by riparian systems and especially how these systems matter to people (O'Neill et al., 2008) and how they decide upon their use and management are the central aspects addressed in this paper.

We analyzed perceptions, activities and agreements (i.e. decisions involving two or more persons and institutions) that local people in rural Mexico have in relation to the riparian environment. We understand perceptions as the combination of what people know, see, feel and value about the environment, in this case the riparia, in a way that allows them to interpret the world through individual and collective experiences and interactions and hence give meaning to their lives (Vargas, 1994; Ingold, 2000). We focused our work on riparian systems, since at present, riparia and rivers are at particular risk as a result of human activities (Nilsson and Svedmark, 2002; Nilsson et al., 2003). Ricciardi and Rasmussen (1999) estimated that the extinction rate for freshwater species of fauna is five times greater than for terrestrial fauna, which is linked to habitat deterioration, including wetland and riparian area transformation.

Viewed as social-ecological systems (Berkes et al., 2003), riparian attributes vary according to (i) the landscape and climate setting (Stanford, 2006), and (ii) the people, cultures and institutions present in a place (Naiman et al., 2005; Mayer et al., 2007). Riparian management decisions and practices shape the interaction between biophysical and socioeconomic spheres and it is expressed in aspects such as land-riparian delimitation, and agreements for access and uses, as well as for conflict management. Riparian - ecosystem - management (Dale et al. 2000, p. 642) is the "process of land and water use decision-making and practices that account for the full suite of organisms and processes that characterize and comprise the 
system". It has consequences on water quality and productive potential, not only for the local but also for the regional-basin scale (Dahl et al., 2007).

Riparian systems can buffer the impacts generated by agriculture as well as forestry, cattle raising and other productive activities taking place in a territory (Lowrance et al., 2000; McClain et al., 2003; Mayer et al., 2007). Both the width (extent) and composition of the riparian areas have been recognized as relevant management aspects related to the ecosystem services they offer such as clean water, sediment balance, erosion control and soil fertility maintenance; streams' shading and cooling, fish production, landscape corridors, habitat for biodiversity and refuge for wildlife; space for recreation, transport and enhancing people's quality of life (Pringle, 2003; Kiley and Schneider, 2005; Janzen, 2008). Rural inhabitants of riparian areas take advantage of all these services.

Riparian areas are considered part of a territory, and are subject to property rights. Therefore, critical aspects for riparian management depend upon the multiple decisions made by national authorities (e.g. agriculture policies), as well as by the owner of the land where streams and riparia are present. It is common to find sites where the riparian vegetation has been replaced by agricultural land and livestock production, and settlements interrupting the relationship between a river and its surrounding land. These decisions reduce the capacity of riparian systems to sustain aquatic life, putting at grave risk terrestrial species that depend upon those forests as biological corridors (Nilsson and Svedmark, 2002).

Riparian areas have been integrated into watershed planning, through diverse policies and ordinances, in order to maintain or recover the benefits they provide. In many countries, these regulations are observed by landowners and are monitored by government agencies. Federal or state institutions are involved in riparian system management decisions, many of which recognize the local features of the system, in both its biophysical constitution of riparia and the social meanings and values that people have (e.g. Guidelines for riparian management edited by Lovett and Price, 2007).

Much scientific work on riparian systems has been oriented to document land and riparian management impacts on rivers (e.g. riparian influences on stream biodiversity), and to understand ecosystem connectedness (e.g. hydrologic connectivity), as well as to understand people's views about riparia (e.g. acceptance of new policies by people). Some studies have gathered local opinions about riparian management (Qureshi and Harrison, 2003; Dutcher et al., 2004; Sweeney and Blaine, 2007) or have collected social views about environmental problems associated with local streams (i.e. Benez et al., 2010), as well as the perception of farmers of the river banks (Ortiz-Arrona et al., 2004). In most of these studies people express the importance of streams, but rarely recognize their own responsibility in protecting them (Dutcher et al., 2004). Local people's practices can reflect how federal regulations are taking place in the daily life of rural areas on land management, showing critical aspects on interacting scales and how they influence each other.

In this sense, Nassauer (1997) has pointed out that "landscapes more apt to be protected are those that satisfy our cultural and aesthetic aspirations" (cited in Naiman et al., 2005, p. 11). Therefore, it is relevant to elucidate the views and strategies of the local actors who inhabit riparian systems, in order to guide management according to those values that shape the territory, with consequences on conservation as well as on human well-being. Citing different authors and addressing the effectiveness of science in the decision-making process, Nassauer and Opdam (2008) established that "if science is not attentive to stakeholder knowledge, research may lack legitimacy because it appears to be irrelevant to place-specific landscape issues". Therefore, the main focus of the present study is to analyze how local people value and manage the riparian system.

This research aimed to document the local values, views and knowledge in order to understand critical aspects of riparian management in rural Mexico. Our questions included: (i) What processes and components do local people recognize regarding a riparian system? (ii) What ecosystem services do people perceive and value within their riparian zones? (iii) What agreements are made on riparia - stream access and conflict management? And (iv) What role is assigned to federal regulations in order to decide on the riparian management? 


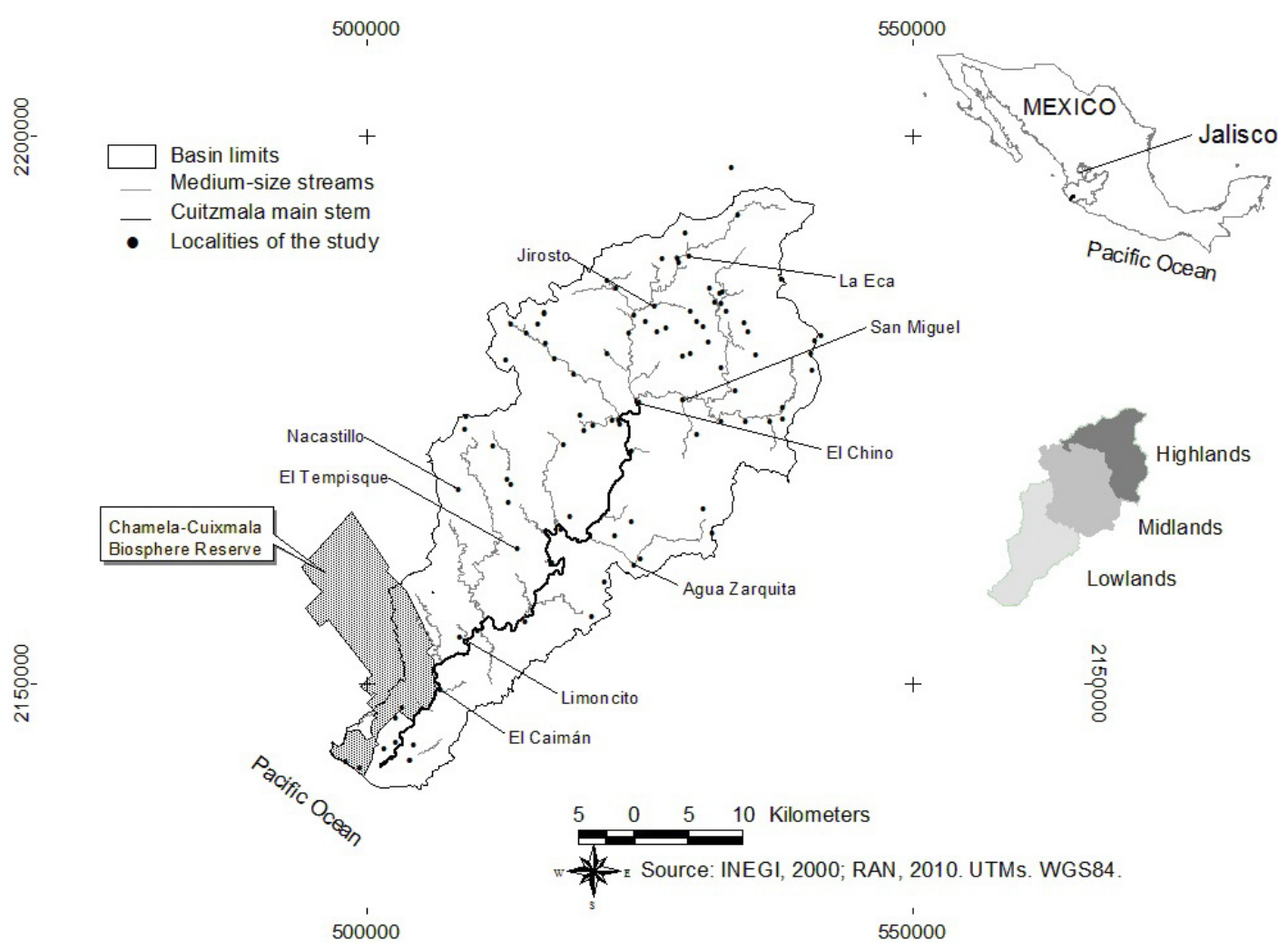

Figure 1

Study site: boundaries, streams and localities in the Cuitzmala river basin.

\section{METHODS}

\section{> THE CUITZMALA RIVER BASIN: BIOPHYSICAL AND SOCIAL FEATURES}

The Cuitzmala river basin (CRB) is located in the state of Jalisco, Mexico. It is an exoreic basin draining to the Pacific Coast between Puerto Vallarta and Barra de Navidad (Figure 1). The CRB is $1086 \mathrm{~km}^{2}$ and is part of the Sierra Cacoma. The climate is sub-humid (Aw) with different humidity types (García, 1973). Rainfall increases with elevation, and vegetation types vary accordingly. Tropical dry forest is the dominant vegetation on the coast, and through the $\mathrm{NE}$ are oak forest (at 400 masl), cloud forest (at 700 masl) and pine-oak forest (at 800 masl). The rainfall annual mean is $750 \mathrm{~mm}$ in the coastal areas and $1500 \mathrm{~mm}$ in the mountains (Piña, 2007). The altitude goes from the sea level to 1170 masl. Most streams (80\%) are small and intermittent. In the upper watershed, narrow and high-gradient streams (>15 degrees) are predominant; in the middle, streams exhibit low gradients and come together in permanent rivers; and, in the lower watershed, most streams are temporal and have very low gradients. The basin territory has been occupied since pre-Hispanic times by indigenous people, who are still represented by a community named Jirosto, in the upper basin (Figure 1). The coastal territory was occupied until the 1940s when government policies promoted the occupation of the Jalisco coast (Castillo et al., 2005). Currently, within the basin there are 95 human settlements, 44 having from 1 to 10 inhabitants and 38 between 11 and 100 . Only 3 settlements have more than 500 persons (CONAPO, 2010). Natural forests have been converted to crop fields and cattle grazing pastures (CIGA, 2010). The transformation process started hundreds of years earlier in the upper section of the basin, accelerating its deforestation process in the last century. Except for a few areas with intensive agriculture (less than $5 \%$ of the basin), most of the conversion has been into rain-fed agriculture and extensive pasturelands. The transformation process in the lower section of the basin, near the coast, is much more recent (no earlier than 1940) stimulated by the construction of the coastal highway (in the 1970s), as well 
as the increasing use of agrochemicals for crops with a peak deforestation rate in the 1980s (slowing down in the last 10 years). However, there are still significant areas with unperturbed forest in the basin (about 45\%), particularly near the coast where the Chamela-Cuixmala Biosphere reserve is located. People get water from springs and permanent streams in the highlands; from small dams in the midlands and from wells in the lowlands. In 1993, a coastal portion of the basin was decreed as part of the Chamela-Cuixmala Biosphere Reserve, a conservation area for dry and sub-humid forests, with 13142 ha (DOF 1993). There are no human settlements inside the reserve and people's livelihoods in the surrounding areas are mainly based on agricultural production but also on the provision of commercial services, including tourism.

Land tenure is represented by private properties (50\% of the basin), ejidos (35\%), and indigenous communities (10\%); federal lands are also represented by a portion of the biosphere reserve (5\%) and the water edges since (according to the National Water Law) streams, river edges and the water belong to the Nation (DOF, 2008); for small streams, the federal land includes a strip $5 \mathrm{~m}$ wide from the maximum water level, and $10 \mathrm{~m}$ for larger rivers.

Governance is an intricate aspect in the region. First of all, because there are three main types of land ownership: private, ejidos and indigenous communities. Private properties belong to single owners, who can decide the cover and use of their land, and can even sell their assets. Ejidos were created after the Mexican Revolution (1910-1917), as a communal land tenure form (Warman, 2001). Most of the ejido land is distributed among the ejido members, who can bequeath the right-of-use to their children but they cannot sell the land. Each ejido has its own Assembly who make decisions (among other things) on land-use issues such as land distribution and land-use conflicts, but rarely engage in specific management decisions, leaving them to each ejido member, except for the pieces of land that are kept as communal property. Finally, there are also indigenous communities who have collectively owned land since before the Spanish colonization. They work in similar ways to the ejidos, with an Assembly who take broad land-use decisions, with the individual farmers taking their own management decisions. As a result, most farmers in the region, either private, from ejidos or from indigenous communities, make their own specific land management decisions of what, when and how to grow on their land.

In 1992 there was an amendment of the Mexican Constitution allowing ejidos and indigenous communities to extract and sell pieces of land. These pieces no longer belong to the ejido or indigenous community and become private property. However, in Mexico ejidos and indigenous communities are considered not only collective land tenure forms, but also historic and respectful social institutions. This situation, and the fact that the change in land tenure requires a slow and highly elaborate official process, means that even in these new private lands owners are engaged in the collective land-use decisions, particularly when they are also members of the ejido community (as frequently happens in small villages). The Assembly for ejidos and indigenous communities (a plenary session with all the members) is the main agrarian authority and is regulated by the Agrarian Law (DOF, 2012). Furthermore, the territories are also part of municipalities and states, which have their own civil authorities. Therefore, all farmers need to be aware of ejido, municipal, state and federal regulations.

In spite of these governance complications, it is important to emphasize that most users in the basin (private, ejido or indigenous) are subsistence farmers with low income and technical possibilities. The exceptions (in less than $5 \%$ of the land) are well-accommodated people owing a narrow strip of land (about $1 \mathrm{~km}$ wide) along the coast where the tourist industry is located. Therefore, most broad land-use decisions in the basin are made through the "ejido" Assembly without much distinction between private or communal ownership of the land, and the most important users of the riparian areas are the subsistence farmers. This is the reason why this study was focused on subsistence farmers as a general type of riparian users.

Although river edges are under federal jurisdiction, their management is based on individual decisions. People take responsibility about the management of riparian systems and streams across their individual portions of land. The permission for using the federal zone, stream water or groundwater is given by the National Commission of Water. In order to incorporate 
watershed planning in Mexico, there are established Watershed Councils in the main regions of the country. They have representatives from the regional stakeholders carrying out projects to manage watershed issues, most focused on water supply for people and industry. Recently (in the last 10 years) diverse regional associations have been created which join municipal, state and federal agencies with citizens' and private institutions (Arellano and Rivera, 2011) to address environmental issues, focused on watershed programs. These associations are becoming an important stakeholder including different scale actors for watershed planning (including public policy elaboration and fund-raising).

\section{> RESEARCH APPROACH AND METHODS}

Our main research approach was qualitative, which is oriented to understand the meanings of phenomena from the local actors' perspective through their own words and expressions (Denzin and Lincoln, 2000). Interviews and participant observation were the two main research techniques (Patton, 2001; Newing et al., 2011). The interview is an open, flexible and enjoyable dialogue about the topics of research interest. During these talks we started to develop interpretations about local people's meanings regarding riparian systems.

Along the basin, we went for long walks with farmers, visiting their parcels and riparian areas, while conducting semi-structured interviews (Robson, 1993) and participant observation. The general topics addressed were riparian flora and fauna knowledge, water-vegetation relations; and most common uses for the riparian zone, the agreements on local access and system boundaries, as well as awareness about federal regulations and processes for conflict management about access and uses of the riparian system. These interviews during the walking tours (a total of 12) were specifically done along the riparian area to capture farmers' values and practices on them. The walking tours were done based on farmers' disposition, interest and time; and they were conducted in different locations: La Eca, Llano del Higo, Jirosto, El Chino, El Tempisque, Nacastillo, Limoncito, El Caimán and Miguel Hidalgo (Figure 1).

Besides these interviews on different sites along the entire basin, we also selected two localities with different socio-cultural contexts to document if there were different perceptions on the issues under study: Jirosto (an indigenous community) and San Miguel (an ejido with a mestizo population). In these localities, semi-structured interviews were conducted with local inhabitants to capture a broader perspective of the farmers in terms of ecosystem services, and helped us to place riparian aspects in a whole management context. The ecosystem services addressed included provision services (wood, fodder, food, medicinal plants and others), regulation services (control temperature, water quantity and quality, air quality and others), and cultural services (intangible benefits that depend on socio-cultural context, e.g. recreation). Even though these interviews were not focused on riparia, issues related to riparian systems came up frequently, allowing us to explore peoples' views and values regarding them. Twenty people were interviewed in Jirosto and thirty in San Miguel. Interviewees were randomly selected while maintaining a gender balance. We determined the sample size by saturation criteria or the point at which no new information was observed in the data (Hernández et al., 2006).

The interpretation process is cyclical and looks for an integration of "the phenomena of interest, the researcher's abstractions, the descriptions, between the complexity of reality and the simplification of that complexity" (Patton, 2001, p. 480). The explanation is based on a detailed and intensive analysis of the information. During data analysis, the data collected and the conceptual framework interact and guide the construction of narratives which are grounded on the data and make visible the meanings that research subjects give to the phenomena under study. This research tradition is known as grounded theory (Strauss, 1995).

Interviews and field notes were transcribed and grouped into three units of analysis: (i) riparian walking tours, (ii) Jirosto interviews, and (iii) San Miguel interviews. In order to interpret the information, we organized and selected the ideas in terms of implications for a specific conceptual framework and the research objectives. The software Atlas-ti (v.5.2) was used to construct and group categories (or codes), and for elucidating relationships between these 
Table I

Streams at ejidos and community lands present at Cuitzmala river basin.

\begin{tabular}{|c|c|c|c|c|c|c|c|c|}
\hline $\begin{array}{l}\text { Ejido } \\
\text { or Community }\end{array}$ & $\begin{array}{l}\text { Position } \\
\text { at basin }\end{array}$ & $\begin{array}{l}\text { Small } \\
\text { streams }\end{array}$ & \begin{tabular}{|l} 
Mediu \\
streams
\end{tabular} & \begin{tabular}{|l} 
Main \\
river
\end{tabular} & \begin{tabular}{|c|} 
Total \\
streams
\end{tabular} & $\begin{array}{c}\text { Length } \\
(\mathrm{km})\end{array}$ & $\begin{array}{l}\text { Area } \\
\left(\mathrm{km}^{2}\right)\end{array}$ & $\begin{array}{l}\text { Proportion } \\
\text { of the basin }\end{array}$ \\
\hline Jirosto & High & 494 & 122 & 0 & 616 & 259.99 & 71.17 & 6.55 \\
\hline Pavelo & High & 192 & 36 & 0 & 228 & 110.38 & 30.34 & 2.79 \\
\hline Purificación & High & 42 & 3 & 0 & 45 & 26.96 & 10.25 & 0.94 \\
\hline Villa Vieja* & Middle & 217 & 23 & 0 & 240 & 155.31 & 51.41 & 4.73 \\
\hline San Miguel & Middle & 147 & 47 & 11 & 205 & 97.09 & 29.41 & 2.71 \\
\hline Agua Zarquita & Middle & 58 & 9 & 7 & 74 & 31.02 & 9.29 & 0.86 \\
\hline La Huerta & Middle & 55 & 12 & 0 & 67 & 27.59 & 9.32 & 0.86 \\
\hline $\begin{array}{l}\text { La Mesa y } \\
\text { Carrizalillo }\end{array}$ & Low & 410 & 51 & 7 & 468 & 210.34 & 54.14 & 4.99 \\
\hline Nacastillo & Low & 318 & 46 & 0 & 364 & 168.09 & 47.72 & 4.39 \\
\hline $\begin{array}{l}\text { Ley Federal de } \\
\text { Reforma Agraria }\end{array}$ & Low & 211 & 15 & 5 & 231 & 88.87 & 22.65 & 2.09 \\
\hline José Ma. Morelos & Low & 196 & 58 & 0 & 254 & 96.68 & 21.91 & 2.02 \\
\hline Morelos & Low & 198 & 13 & 0 & 211 & 84.04 & 18.95 & 1.75 \\
\hline General Morelos & Low & 120 & 0 & 6 & 126 & 52.53 & 14.83 & 1.37 \\
\hline Rincon de Ixtán** & Low & 54 & 0 & 0 & 54 & 30.23 & 6.53 & 0.60 \\
\hline El Higueral & Low & 46 & 0 & 0 & 46 & 20.7 & 5.38 & 0.49 \\
\hline El Cedro & Low & 230 & 27 & 1 & 258 & 117.55 & 31.46 & 2.90 \\
\hline Total & & 2988 & 462 & 37 & 3487 & 1577.37 & 434.75 & $40.03 \%$ \\
\hline
\end{tabular}

* "Villa Vieja" and "Ex-Hacienda Villa Vieja" were counted together.

${ }^{\star *}$ Rincón de Ixtán lands were bought and incorporated into the protected area.

through diagrams. Based on the diagrams, we developed narratives (Strauss, 1995; Muhr and Friese, 2004) and preferred direct quotes to give an actual voice to the ideas and opinions of interviewees (in their own words), rather than the complex diagrams (Baxter and Eyles, 1997). However, we also included in parenthesis the frequency per category $(n)$ that is the number of mentions of ideas expressed by interviewees, and in bold $(n)$ the number of people that gave a particular opinion. We indicated by the letters in parenthesis (PO) the information obtained from participants' observations. Therefore, narratives (results) are based on all types of information: participant observation, riparian walks and interviews. These results not only reflect the responses of participants from interviews but also focus on what is important to them in order to show how the social experience is created and how people give it significance (Denzin and Lincoln, 2000). The riparian system was examined as a whole with biotic and abiotic components and embedded in the local knowledge and peoples' understanding about relationships between the systems' components.

\section{RESULTS}

The places visited with the farmers along the basin constitute the ejidos and community territories, which are drained by hundreds of streams that channel into the main river, so riparian systems and their joint productive lands are managed as a whole (Table I).

It is notable that no substantial differences were found in the perceptions (understanding, feeling, values) about the river and the riparian system among the participants; nor between the indigenous community and the ejido members or between men and women. The analysis shows that local people did recognize differences between streams and riparia along the basin, as well as values and benefits derived from the riparian system and perceive the problems that are generated as a result of its mismanagement. Practices taking place in the riparia are related to the stream and river positions in the basin, but no differences are marked among farmers along the study site. 
Table II

Riparian plant species most mentioned by farmers in the basin.

\begin{tabular}{|l|c|c|c|}
\hline Common nam & Scientific nam & Common nam & Scientific nam \\
\hline Ahuijote & Vitex hemsleyi Briq. & Higueras & Ficus spp. \\
\hline Arrayán & Psidium sartorianum (O.Berg) Nie & Huizache & Acacia farnesiana (L.) Willd \\
\hline Barcin & Cordia eleagnoides DC. & Madera & Tabebuia spp \\
\hline Botoncillo & Cordia alliodora (Ruiz \& Pav.) Oke & Mojote & Brosimum allicastrum Sw. \\
\hline Capilotate & Rhipidocladum sp. & Primaver & Tabebuia donnell-smithii Ros \\
\hline Capulín & Prunus sp. & Sabino & Astianthus viminalis (Kunth Baill. \\
\hline Cebollín & Cyperus sp & Sauc & Salix taxifolia (H.B.K.)-Kunth \\
\hline Habill & Hura polyandra Baill & Zarzamil & Cordia dentata Poir. \\
\hline
\end{tabular}

\section{> LOCAL KNOWLEDGE AND VALUES OF THE RIPARIAN AREAS}

\section{Flora and fauna}

Participants recognized different types of streams and riparian areas as a function of their location in the watershed itself, as well as a function of different rivers' behavior over the course of the year. The participants associated the river's width and water seasonality with the presence of certain plant species, many of which were highly valued, as was commented in El Tempisque: "Over by the river, there are woody trees (Tabebuia donnell-smithii Rose). Over here there is only Huizache (Acacia farnesiana (L.) Willd.). That's why we cut them down" (3). Table II shows the plant species most mentioned by the farmers.

Problems associated with flooding of the riparian areas and agricultural parcels were often mentioned by the participants living in the lowlands (6), who also commented about the benefits of leaving certain trees along the edge of the river: "We don't clear the edge of the river to protect ourselves so that the water does not take the soil." Even more, one of the participants was experimenting with riparian species, finding that the "Zarzamil" (Cordia dentata Poir.) are particularly useful, protecting their river banks and agricultural fields from erosion during severe flooding events.

Participants mentioned animal species that inhabit the river or riparian area and others that drink from it. Fish, crabs and "chacales" (Macrobrachium spp.) (8) are the aquatic species most mentioned and highly valued for food consumption (in the Nahuatl language chacalín means shrimp: Solórzano, 2008). Among the terrestrial species mentioned are "raccoons" (Procyon lotor L.), "lions" (puma, Puma concolor L.) and "tigers" (jaguar, Panthera onca L.) as commented by a participant: "When the water upstream dries up, [the animals] come down here. They look for water just like us. In the rainy season opossums come (Didelphis virginiana Kerr) as well as ocelots (Leopardus pardalis L.; Ceballos and Miranda, 1983)".

\section{$>$ WATER-SOIL-VEGETATION RELATIONS}

The presence of humid soils in the flat riparian areas strongly defines the use of these areas since farmers prefer to crop there "...at the edge the soil is more loamy and fresh and has more leaf litter" (4). The flow of water and materials is considered a process that intervenes in the structure and fertility of the area, since the plants can change the river as a result of excessive erosion or sedimentation deposit (3). The majority of local inhabitants associate riparian vegetation with water quality (13). Vegetation is considered a reflection of the river's health, as was expressed by a participant from El Caimán: "When the water isn't well the plants don't do well. That's where the water quality is reflected. Like the skin reflects the health of the body". The participants explained that tree roots retain soil across the watershed (10), including in the riparian areas. Extraction of water is preferred by means of shallow wells in the riparian area to reduce the sediment count (8). Roads, excessive fertilizer, the use of streams for waste transport and edge deforestation were mentioned as the main causes 
of poor water quality (10). During the field work empty containers of agrochemicals were occasionally found in parcels; however, farmers insisted that they have reduced their use. Participants acknowledged that their activities in the rivers and riparian areas have effects on downstream water users (10).

\section{> ECOSYSTEM SERVICES PROVIDED BY RIPARIAN SYSTEMS}

One of the most important benefits of the riparian system mentioned by the participants was its recreational use as well as its source of food (e.g. chacales) (12). People made clear references to changes in the landscape and the uses of the streams of the territory, in the last 30 years. They perceive less water in streams (11) and its lower quality (7) than around 30 years ago. In San Miguel they said that: "[The river water] was clean, we even used to drink it when we came to swim, but we don't do it anymore because we are upset knowing that animal waste goes into the river. That is disgusting!" Interviewees explained that people have gotten sick from drinking or swimming in the river (5). People recognize the linkages between the deterioration of the riparian system and the stream and the use of agrochemicals (2), a general contamination of the basin (3), bad management of feedlots upriver (1) or simply because there are "more people", generating more waste and pollution (1). In San Miguel people mentioned that the stream contamination (6) occurs "because they use it as drainage and everything gets dumped in it. Only the streams that come down from virgin hills have better water. But in terms of the river, it is really bad, we can't use it!" Interviewees from San Miguel also associate vegetation with water from the channels and springs (9): "I have waterholes in my paddock and I take good care of them. I clean them and maintain the plants that grow at their edge so they always have water because, if I cut the trees, the waterholes will dry up because the trees are gone". They specify that the figs (Ficus spp.) play an important role in "retention and temperature" of the water. They also relate less discharge due to rainfall reduction (5). They said, "[Years] before, it rained a lot and you could hear the water flowing in all the streams. Now, they barely run... because it doesn't rain as much." In Jirosto, interviewees recognized that the maintenance of the river water depends on the filtration promoted by tree roots (3): "There are water holes that come up from between the trees and the water comes out from between the roots and is filtered there". Inhabitants highly value agricultural parcels in the riparian zones (10): "Water is life for the earth and for us"; "It's beautiful to be at the edge"; "I love being on the edge because it's better for production".

\section{> MANAGEMENT PRACTICES IN THE RIPARIAN AREAS}

In most of the productive lands along the basin, riparia have been integrated into the productive surface. This integration means a complete removal of the original vegetation up to the edge of the river channel. The water dynamic is one of the aspects taken into consideration by farmers with regard to the activities carried out in the riparian areas (10).

In spite of the fact that no substantial differences were found in the values regarding the river and the riparian system among the participants (mentioned above), farmers do recognize the ecosystem differences between upper and lower levels of the basin, and riparian management differences were identified. For example, agriculture in the lowlands is diminished during the wet season, as was commented by a participant in this zone: "[Floods] are not predictable, so we don't cultivate during the rainy season, it is too risky" (5). In the highlands, crops are grown almost year round in riparian zones. Riparia in the upper watershed tend to be narrower and with a steeper slope gradient in comparison with the riparia in the lowland, therefore crop invasion is much lower in the upper basin.

Table III lists the activities mentioned by participants according to their management and accessibility for the different riparian users at the study site. Riparian areas, named "river beaches", are used by local families for rest and recreation. They also mentioned uncomfortable aspects in the riparian areas that lower their recreational potential, such as the presence of stinging plants (1) and excessive sand (1). 
Table III

Diversity of activities carried out in the riparian areas, the main users and the agreements on accessibility for neighbors and visitors.

\begin{tabular}{|c|c|c|}
\hline Activities & $\begin{array}{l}\text { How is the riparian } \\
\text { area managed }\end{array}$ & $\begin{array}{l}\text { Who can access } \\
\text { and use the riparian area }\end{array}$ \\
\hline Recreation & $\begin{array}{l}\text { Some trees are maintained } \\
\text { for shad }\end{array}$ & $\begin{array}{c}\text { Public access with some restricted sites } \\
\text { Most users are local families }\end{array}$ \\
\hline Cattle raising & $\begin{array}{l}\text { Trees for shade, crossing roads } \\
\text { and fences to care for the cattl }\end{array}$ & $\begin{array}{c}\text { Access to other farmers } \\
\text { by personal agreement } \\
\text { Users are local farmers and neighbors }\end{array}$ \\
\hline Grass cultivation & $\begin{array}{l}\text { Most cleared surface, some } \\
\text { "water caretaker" trees }\end{array}$ & Land owner \\
\hline $\begin{array}{l}\text { Annual crops } \\
\text { in highland }\end{array}$ & $\begin{array}{l}\text { Tree coverage at water edg; } \\
\text { it depends on the local slope }\end{array}$ & Land owner \\
\hline $\begin{array}{l}\text { Annual crops } \\
\text { in lowlands }\end{array}$ & $\begin{array}{l}\text { Tree coverage enough to protect } \\
\text { the soil erosion in high flood }\end{array}$ & Land owner \\
\hline $\begin{array}{l}\text { Caring for } \\
\text { woody species }\end{array}$ & $\begin{array}{c}\text { Tree species } \\
\text { valued are presen }\end{array}$ & Land owner \\
\hline $\begin{array}{l}\text { Macro-invertebrate } \\
\text { fishing }\end{array}$ & $\begin{array}{l}\text { Tree coverage is preferred } \\
\text { and most valued macros come } \\
\text { from forested upstream sites }\end{array}$ & $\begin{array}{c}\text { Public access with some restricted sites } \\
\text { Most users are local families }\end{array}$ \\
\hline Orchards & $\begin{array}{l}\text { Few or null tree coverage } \\
\text { Most riparia are used }\end{array}$ & Land owner \\
\hline $\begin{array}{l}\text { Sand and gravel } \\
\text { extraction }\end{array}$ & $\begin{array}{l}\text { Floodplain extraction of sediment, } \\
\text { high exposure to land-edge erosion }\end{array}$ & $\begin{array}{c}\text { Access with previous permission } \\
\text { by the owner and the Ejido authority, } \\
\text { if it is the case } \\
\text { Local and regional users to get } \\
\text { gravel for construction }\end{array}$ \\
\hline $\begin{array}{l}\text { Water extraction } \\
\text { for land, domestic } \\
\text { activities and } \\
\text { road construction }\end{array}$ & $\begin{array}{l}\text { Most wells located in riparian areas } \\
\text { are inside sandy floodplains, } \\
\text { with low or null vegetation }\end{array}$ & $\begin{array}{l}\text { Access to other farmers } \\
\text { by personal agreement } \\
\text { Local families }\end{array}$ \\
\hline Dwelling & $\begin{array}{l}\text { Little tree coverage. There are } \\
\text { trees for shade and shrubs } \\
\text { against high flood events }\end{array}$ & The owner of the land / house \\
\hline $\begin{array}{l}\text { Experiments with } \\
\text { tree species }\end{array}$ & \begin{tabular}{|c|} 
High tree coverage; woody \\
valued species are sold and replace \\
that protect river banks
\end{tabular} & Land owner \\
\hline
\end{tabular}

Livestock owners use the riparian areas as access to streams and as rangeland. Some dwellings are on the riparian zone so water can be used directly for household consumption (e.g. for gardens and/or care of chickens and pigs). In watershed lowlands, some portions of the main channel are fenced, so locals open the gate to allow passage of cattle into the riparian zone or directly into the river channel (OP). The placement of theses fences is a decision of the farmer owning the land adjacent to that riparian area in order to take care of his cattle. One participant from El Caimán commented: "There are fenced pools [inside the riparian zone and stream], that have to be rebuilt every year because the river takes them out".

Local people recognize that land-parcel location in the basin results in particular water dynamics (e.g. flooding risk) and a group of plant species. They understand that local riparian features (e.g. bank slopes, soil humidity and the size of the floodplain) define activities or productive opportunities such as agriculture, cattle raising or recreation.

The incorporation of the riparian area into production depends, primarily, on the necessity of the farmer to increase his productive surface. However, as mentioned previously, 
the particular features of the stream or river and the accompanying riparian area in a specific point of the basin is also an important element to decide its use. This is to say that the riparian zone strip is contracting and expanding constantly, along the fluvial network, in a high correlation with both geomorphic - hydrological and vegetation features, and social needs and values.

\section{> AGREEMENTS ON ACCESS AND CONFLICT MANAGEMENT REGARDING RIPARIAN AREAS}

As collective groups, neither the ejido members, nor the indigenous people or private property owners (OP) have formal agreements (signed documents) to regulate the use of or access to their river and riparian areas (10). However, they all recognize that the care of the river edge is important to maintain the water body. Each inhabitant is in charge of managing the riparian area adjacent to their parcels. Some farmers use fences and divisions to manage livestock in the riparian areas (5): "Yes, one uses fences so that the cattle don't get lost, but everybody can pass through." The riparian area represents access to water to which all inhabitants have a right of use (10). In the case of recreational activities, access to the river beaches is open, although in some portions of the basin it depends on the land owner (5) (Table III).

Cattle raising is a high water-consumption activity which promotes spatial agreements among local inhabitants, mainly to ensure access to the riparian area and to the stream water, for cattle water supply, along the whole basin. Agreements on use of and access to the riparian area are also tied to the diversity of activities carried out at the water edge (Table III).

Agreements are taken by farmers who belong to an ejido or a community as well as between them and private owners. All of them recognize that "everybody needs water and has the right to access to it". So, entering the riparian zones is usually first granted to the owner of the land adjacent to it. However, other farmers also have access to get stream water or groundwater. In the entire basin farmers take care of the stream edge and water, as well as the springs located on their lands. This is a tacit agreement every person recognizes and it is related to past experiences when some farmers cleared all the river edge and the vegetation around the springs, reducing water quality (3). In spite of the existence of tacit agreements to avoid complete deforestation of the riparian area, in the Cuitzmala basin many farmers fail to comply with it (OP).

At present, people do not know what authority they should approach when conflicts arise regarding the riparian system. They do realize that riparian areas are federal land; however, the authorities at federal level are scarce in the area and are hard to approach (more below). Therefore, conflicts are managed, at first, by the local authorities (ejido or municipal) but there is confusion about which authority should be attending to them. Here are some examples of conflicts mentioned during the interviews regarding access and degradation of the streams and riparia: (i) there was a person illegally attempting to obtain a riparian territory, having acquired just temporary access to the water; the conflict was managed with the intervention of the local (ejidal) agrarian authority; (ii) someone else used herbicides to extract chacales from the river, provoking poisoning of the stream species and the livestock; this problem was managed by talking with the person responsible without the intervention of any authority; and (iii) there was an excessive extraction of sand from the riparian area in the midlands for road construction without having the permission of the corresponding ejido; this conflict had not yet been resolved at the time of the interview.

\section{> ROLE OF GOVERNMENT REGULATIONS IN RIPARIAN MANAGEMENT DECISIONS}

In spite of the fact that the inhabitants of the watershed know that the edge of the stream is federal property, they are unaware of the boundaries of the zone indicated by law. However, even if the distance dictated by the law is determined, this law does not establish any management guidelines. Therefore, if permission to use the riparian zone is granted, the beneficiary can do whatever he likes with it. 


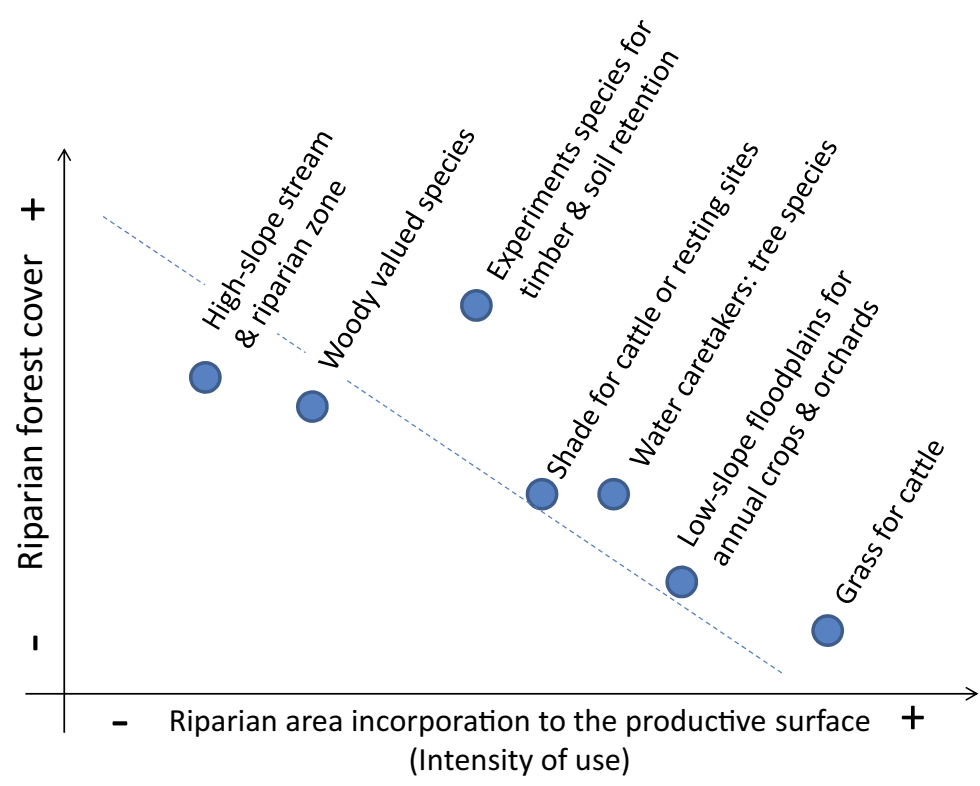

Figure 2

Riparian use intensity vs. riparian forest cover.

For local inhabitants in the lowlands, the maintenance of the riparian area is important to avoid erosion as a result of the high water flows (5). In the highlands, the extent of the riparian forest depends on the slope (3), as was commented by one interviewee: "In order to clear the land, it depends on how the land [form] is; if it is steep there isn't much to work with; when it is flatter only a meter or two is cleared..." Some interviewees mentioned that the permits for the use of wells, springs or riparian areas are granted by the corresponding state and federal entities, and they turn to the municipal authorities to obtain permits for cropping (10). There is clear acceptance and recognition of the riparia as federal property, including the distances dictated by the law. Moreover, taking care of riparian areas is related to the experience of the local people in the basin, too. No authorities visit the zone to guide or delimit this zone. The National Commission of Water has a monitoring network, which includes only two sites relatively close to (but outside of) the study region. That expresses the poor government capability at the federal level to manage and assess the water status and the local practices' impacts on it (http://www.conagua.gob.mx/atlas/mapa/24/index_svg.html).

\section{DISCUSSION}

\section{> ENVIRONMENTAL DISCREPANCIES}

In spite of being highly valued places, the riparian areas in the region showed significant levels of deforestation. With the exception of the Chamela-Cuixmala Biosphere Reserve in the low basin and the sites designated as reserves by the inhabitants, the basin has been transformed by production activities and human settlements. The riparian areas adjacent to productive lands show strong impacts with low or null tree cover (OP). Footpaths and livestock trails cross constantly along the streams. The intensity of use of riparian areas varies as a function of the local criteria stated above (OP) and activities carried out in the adjacent land (Figure 2). The differences found between the positive values of the riparian areas versus the current degradation observed in the region are clear signs of existing tensions and conflicts between what is recognized as relevant versus what people need to do as part of their livelihood activities. This tension was also detected by Dutcher et al. (2004) when working with landowners in Pennsylvania; and Benez et al. (2010) regarding stream pollution in Chiapas, México. From our 
Riparian social-ecological system management

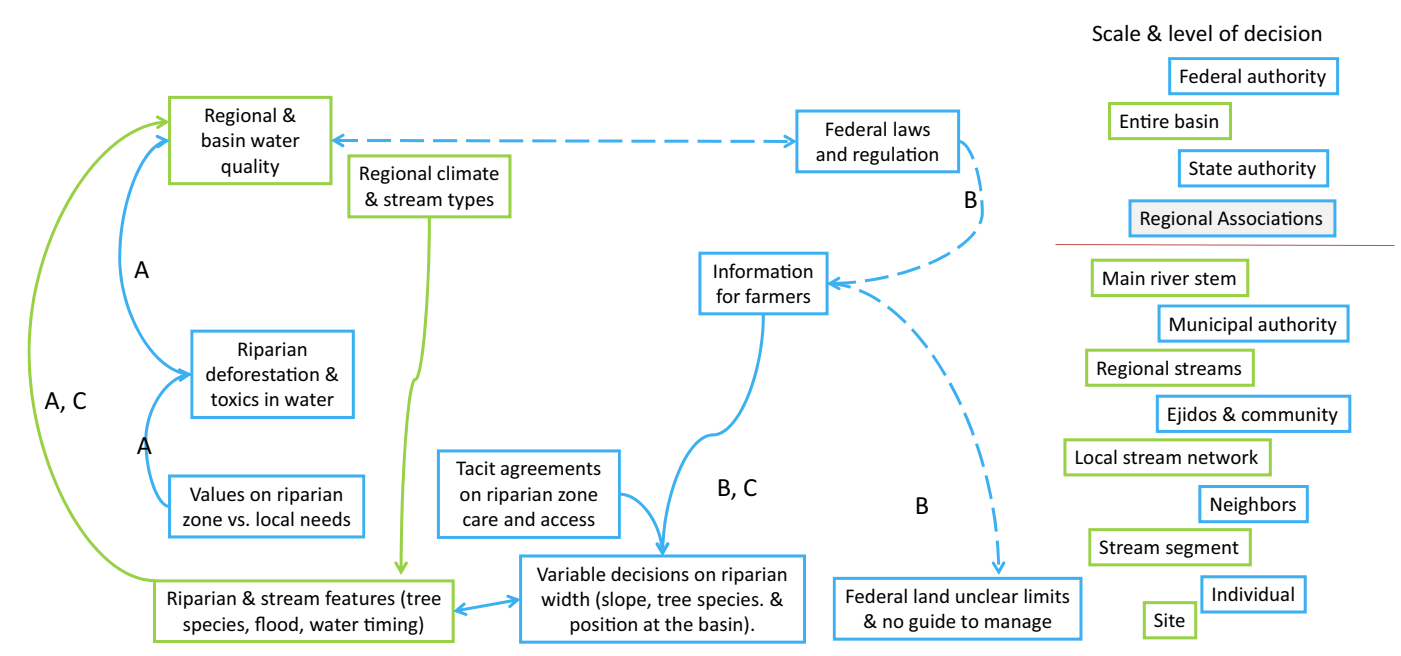

Figure 3

Components and relations concerning riparian social-ecological system management in the Cuitzmala river basin.

Green lines and squares represent biophysical features and processes and blue ones represent socioeconomic ones. Dashed lines represent weak relations in reference to the participants' opinion. Letters represent the discussion section: (A) environmental discrepancies; (B) boundaries of the system and (C) individual costs and collective benefits. On the right side the different scales on which decisions are taken regarding the riparian zone are shown. The line across and shaded box indicate the new regional associations' place in this hierarchy.

results we can state that there are species and ecological processes that are valued by farmers, but it has been difficult for them to establish a compromise between the benefits obtained from riparian forest with their needs. This results in a slow and constant degradation of the entire fluvial network recognized by the same interviewees.

In this sense, Paré and Fuentes (2007) pointed out the local level issues are not isolated from economic, political and cultural contexts that exist on a larger scale. The ability of local people to take full responsibility (including constructing agreements and rules) for the sustainable use of an ecosystem depends, to a large degree, on what is decided at higher institutional levels. In Cuitzmala river basin, riparian area uses, access and covering strongly depend on the productive activities carried out in the adjacent land. Particularly, regarding riparian systems, large-scale aspects mix with a high sense of localness shown by streams and riparia in both biophysical features and social values (Figure 2). Discrepancies between peoples' values expressed in the interviews and the status of conservation of riparian areas combine the worries about land production needs and caring for land-water.

\section{> BOUNDARIES OF THE RIPARIAN SYSTEM}

Multiple studies across the globe have identified the width of the functional edge of riparian areas as one of the variables that drives ecosystem processes and, therefore, their services (Young, 2001; Mayer et al., 2007).

From our results it is possible to state that riparian areas are appreciated, known and used by local people. The riparian area width is changing constantly, mainly by the influence of the local farmer, who incorporates this zone into the productive surface, and gains direct access to soil moisture and water. Given that the riparian forest cover and condition is tied to the adjacent land activities, it is necessary to consider the stream - riparia - parcel (SRP) as interacting components, which integrate both biophysical processes, social values and the decisions taken on them.

Riparian areas represent a sensitive system where both terrestrial and aquatic fauna interact and depend on each other. In this sense, to consider the systemformed by the SRP allows 
a better understanding of the relationship between the water body and the productive lands, and how it changes in a given watershed.

Confusing boundaries with no guiding principles to manage riparian areas, as well as a lack of authority to manage conflicts regarding them, occurred at the study site.

\section{$>$ INDIVIDUAL COSTS AND COLLECTIVE BENEFITS}

The S-R-P system changes according to local farmer needs, indicating that the riparian area condition results from individual decisions, which may have direct consequences on collective benefits (e.g. water quality). In the Cuitzmala basin we found the same situation described by Sweeney and Blaine (2007) in which people do recognize a collective obligation to ensure that management of their lands does not compromise water quality, but there is a limited awareness of how their practices contribute to water degradation. As Benez et al. (2010) also found, people recognize the poor quality of water in local streams but passed the responsibility to other social groups.

Various authors agree that the high costs (monetary and work investment) of maintaining riverine forests include costs derived from the non-incorporation of the riparian zone into the productive surface (Qureshi and Harrison, 2003; Dutcher et al., 2004; Sweeney and Blaine, 2007). At the parcel level, these costs fall back on each of the local farmers; however, the majority of the benefits are reflected on larger temporal and spatial scales (i.e. the fluvial network).

Services such as shade, temperature maintenance and habitat provision for local species are experienced in the same zones where forests are maintained, while regulation of quantity and quality of water (as in the maintenance of hydrologic connectivity) are manifested at a regional level (Thorp et al., 2006; Stanford, 2006).

We also detected two contrasting scales involved in riparian management in the region: (1) national level ordinances which determine the federal lands and (2) a local level in which the use of the riparian area is determined by the needs of the farmer owning the adjacent land and the particular geomorphological and ecological conditions of the site. It seems there is a lack of an intermediate scale, on a more regional level, to allow the integration of these two extremes.

\section{> OPTIONS AND SUGGESTED ACTIONS}

From the perspective of this study, the SRP system can help to visualize the role of the local riparia as an ecotone between land systems and the water network. Different pressures on land by productive schemes (i.e. policy or market drivers) can represent different pressures on riparian systems, which are possible to assess by means of focusing on the SRP as a new boundary.

We all know (scientists and local people) that the decisions and actions of the inhabitants of the upper river basin directly affect those in the lower basin and locals understand this, but they have not defined a management strategy in which all stakeholders, within the watershed, can participate to resolve their common problems.

These large-scale connections derived from scientific understanding should be shared with local farmers, complementing each other's knowledge systems.

Based on our findings, and considering similar experiences in other case studies, it seems that what it is needed in our study region is a facilitation process to support the interaction between different actors, including producers, authorities and scientists. By allowing the sharing of their ideas, visions and needs, it will be easier to design and formulate new agreements and policies, as well as to generate and provide the pertinent knowledge to support such policies.

A basin-level institution can lead the integration of the federal ordinances with local needs and values. The recent associations formed in the regional context can be part of the facilitation mechanism that is needed. 
Sharing "co-production" of knowledge (Roux et al., 2006) between local people and researchers can be of great benefit to clarify the functional responses of riparian areas in the basin as a whole in the face of everyday activities, including the ways in which the water connects people (Cotler, 2010). To take into account the multiple stakeholder perspectives can help to elucidate discrepancies among stakeholders so clear guides to manage nature could be stated. A riparian system is not only large and complex, but also includes the use of a mobile and fluid resource that is interconnected to all ecosystem and social processes: water.

The Cuitzmala basin regional system, with more than $1000 \mathrm{~km}^{2}$, is the type of intermediate scale between the local (ejido) and federal levels that is required to integrate these two extremes. With an integrated basin management approach (Christensen, 1996; Stanford and Pool, 1996; Maass and Cotler, 2007; Castillo and González-Gaudiano, 2010) not only technical practices are included, but also communicative and institutional actions to foster better understanding and multi-level governance arrangements. With this approach, the Cuitzmala settlers will be able to evaluate the impacts of their own decisions and, following an adaptive management strategy, will have a better chance to transit to a more sustainable management of their riparian areas.

\section{SUMMARY AND CONCLUSION}

We found that local people do know and value riparian systems and their ecosystem services. The riparian management in the study area strongly includes local owner criteria which are guided by the activities carried out in the site and the agreements with neighbors and visitors to the stream. Local (fine-scale) considerations to manage the riparian zone include: (1) the location in the basin and water timing of the stream related to it; (2) the slope of the stream and riparia; (3) the value of the plant species occurring there; (4) the floodplain size and its productive/recreation potential; (5) the owner's needs for shade or space for production; and (6) the neighbors' agreements to let them pass through the land/riparia to get water or to rest at the "river beach".

However, elements of environmental degradation were found which show a discrepancy between values, knowledge and practices. Degradation is related to changes in natural systems that reduce the benefits they received before (30 years ago). Recreation and food are the services most mentioned by people, although at present there is a reduction in their provision, because of the current pollution in some portions of the basin. It is clear that they need to take decisions on an everyday basis taking into account their needs and what is allowed mainly by their own tacit agreements. Land production drives the use of the riparian zone, expressed in the expansion and contraction of the in-site forest cover. This "mobility" of the riparian forest is the reason to propose the stream-riparia-parcel system to address research on riparian management and its consequences on the fluvial network as a whole.

Although Mexican law acknowledges water (and the biophysical systems in which this critical element moves) as a federal domain, at the local level inhabitants do not know enough about the laws and regulations on this matter, and they do not receive the necessary information to properly deal with it. The lack of clarity about the legal limits for federal lands is worrying, and even the lack of guidelines to manage the riparian zone. The CRB is not an isolated case in Mexico. In fact, there is little understanding of the federal land limits, and the proper practices to take care of it given the high sensitivity of the system, at the country level.

Under these conditions, knowledge of the riparian system and agreements constructed at the local level are not sufficient for a long-term sustainable management of riparian areas. This requires a design that takes into account its characteristics on a local scale, but also its relationships with other larger (basin) scales.

In our view, the development of such designs should be constructed through the negotiation processes between local, regional and national interests. In this sense, it is proposed that the regional associations, working within an integrated basin management approach, should become a stakeholder joining local and national or state level. With this whole-basin approach 
the co-production of knowledge should provide a deep understanding of the connectedness of the basin, where riparian systems have a critical role. This process should also incorporate the values expressed by people and the scientific knowledge generated about riparian zones and the socio-political characteristics of the CRB in the region.

By these means, the sense of co-responsibility in land management strategies among different stakeholders will improve. In this context, the documentation and understanding of local values, knowledge and agreements become a strategic tool for facilitating the transit into sustainable management practices.

\section{ACKNOWLEDGEMENTS}

The authors would like to thank the local inhabitants of the Cuitzmala basin, as well as the workers of Chamela Biological Field Station, affiliated with the Universidad Nacional Autónoma de México (UNAM), for their support. The identification of botanical specimens was conducted with the help of Emily Lott. We are also grateful for the technical collaboration of Roger Guevara, Raúl Ahedo, Rosario Langrave, Salvador Araiza, Abel Verduzco, Heberto Ferreira, Alberto Valencia, Atzimba López and Lucía Martínez. This study was financed by the SEP-CONACYT project (90955) and the Fondo Mixto CONACYT-Jalisco (99050). This study constitutes a part of the Ph. D. thesis in Ecology and Natural Resources Management realized by Adriana Flores-Díaz at the Instituto de Ecología, A.C. with a grant from CONACYT (192408). The manuscript has greatly benefited from the comments and suggestions from Michael McCall (CIGA, UNAM), Peter Gerritsen (CUCSUR, UdeG) and a couple of anonymous reviewers. Thanks to all of them!

\section{REFERENCES}

Arellano R.A. and Rivera P., 2011. Asociacionismo municipal y medio ambiente. La junta intermunicipal del río Ayuquila, Jalisco. Espacios Públicos, 14, 32-56.

Baxter J. and Eyles J., 1997. Evaluating qualitative research in social geography: establishing "rigour" in interview analysis. Trans. Inst. Br. Geogr., 22, 505-525.

Benez M.C., Kauffer M. and Álvarez Gordillo G., 2010. Percepciones ambientales de la calidad del agua superficial en la microcuenca del río Fogótico, Chiapas, Frontera Norte, 22, 129-158.

Berkes F., Colding J. and Folke C. (eds.), 2003. Navigating social-ecological systems: building resilience for complexity and change. Cambridge University Press, New York, $417 \mathrm{p}$.

Cárdenas J., Robles O. and Santana F., s/f. Monografía de la comunidad de Jirosto. (Manuscript no published).

Carpenter S.R., Mooney H., Agard J., Capistrano D., De Friese R.S., Díaz S., Dietz T., Duraiappah A.K., Oteng-Yeboah A., Pereira H.M., Perrings C., Walter V.R., Sarukhán J., Scholes R.J. and Whyte A., 2009. Science for managing ecosystem services: Be yond the Millennium Ecosystem Assessment. Proc. Natl. Acad. Sci., 106, 1305-1312.

Castillo A. and González-Gaudiano E., 2010. La educación ambiental para el manejo de ecosistemas: el papel de la investigación científica en la construcción de una nueva vertiente educativa. In: Castillo A. and González-Gaudiano E. (Coord.). Educación ambiental y manejo de ecosistemas en México. Secretaría de Medio Ambiente y Recursos Naturales; Instituto Nacional de Ecología, 9-33.

Castillo A., Magaã A., Pujadas A., Martínez L. and Godínez C., 2005. Understanding the Interaction of Rural People with Ecosystems: Case Study in a Tropical Dry Forest of Mexico. Ecosystems, 8, 630-643.

Ceballos G. and Miranda A., 1983. Los Mamíferos de Chamela, Jalisco. Manual de campo. Instituto de Biología, UNAM, México D.F., 436 p.

Christensen N.L., Bartuske A.M., Brown J.H., Carpenter S., Dt'Antonio C., Francis R., Franklin J.F., Macmahon J.A., Noss R.F., Parsons D.J., Peterson C.H., Turner M.G. and Woodmansee R.G., 1996. The report of the Ecological Society of America Committee on the scientific basis for ecosystem management. Ecol. Appl., 6, 665-691. 
Centro de Investigaciones en Geografía Ambiental - CIGA-. 2010. Mapa de uso del suelo y vegetación. Escala 1:50 000. Basado en Landsat TM 2009. Universidad Nacional Autónoma de México.

Comisión Nacional del Agua (National Water Commission). Water monitoring network. Map display, search date: November 2013. http://www.conagua.gob.mx/atlas/mapa/24/index_svg.html.

CONAPO (Consejo Nacional de Población)., 2010. Censo de Población y Vivienda 2010. México.

Cotler H., 2010. Las Cuencas Hidrográficas de México. Diagnóstico y Priorización. Secretaría de Medio Ambiente y Recursos Naturales - Instituto Nacional de Ecología - Fundación Gonzalo Río Arronte, México, $232 \mathrm{p}$.

Dahl M., Nilsson B., Langhoff J.H. and Refsgaard J.C., 2007. Review of classification systems and new multi-scale typology of groundwate-surface water interaction. J. Hydrol., 344, 1-16.

Daily G., 1997. Introduction: What are ecosystem services? In: Daily G. (ed.), Nature's services. Societal dependence on natural ecosystems, Island Press, USA, 1-10.

Dale V.H., Brown S., Haeuber R., Hobbs N.T. and Huntly N., 2000. Ecological Principles and Guidelines for Managing the Use of Land. Ecol. Appl., 10, 639-670.

Denzin K. and Lincoln S., 2000. Handbook of qualitative research, Sage Publication. Thousand Oaks, USA, $1065 \mathrm{p}$.

DOF (Diario Oficial de la Federación), 1993. Decreto oficial por el que se declara Área Natural Protegida con el carácter de reserva de la biosfera, la región conocida como Chamela-Cuixmala, ubicada en el Municipio de La Huerta, Jal. México. DOF 30-12-1993.

DOF (Diario Oficial de la Federación), 2008. Declaratoria de la Ley de Aguas Nacionales. DOF 18-042008.

DOF (Diario Oficial de la Federación), 2012. Texto vigente de la Ley Agraria. Last modifications published on: DOF 09-04-2012.

Dutcher D., Finley J.C., Luloff A.E. and Johnson J., 2004. Landowner Perceptions of Protecting and Establishing Riparian Forests: A Qualitative Analysis. Soc. Nat. Res., 17, 329-342.

García E., 1973. Modificación al sistema de clasificación climática de Kooppen (adapted to Mexican Republic). Instituto de Geografía. UNAM, México, 71 p.

Grumbine R.E., 1994. What is ecosystem management? Cons. Biol., 8, 27-38.

Hernández R., Fernández-Collado C. and Baptista P., 2006. Metodología de la Investigación. McGraw Hill, México, $850 \mathrm{p}$.

Ingold T., 2000. The perception of the environment. Essay of livelihood dwelling and skill. Routledge, London, $480 \mathrm{p}$.

INEGI (Instituto Nacional de Estadística Geografía e Informática)., 2000. Digital cartography. UTMWGS84. Federal Government, Mexico.

Janzen K., 2008. Hyporheic flow in a mountainous riverine system. Thesis of Master in Science. University of Saskatchewan, Saskatoon, Saskatchewan, Canada, 86 p.

Kiley D. and Schneider R., 2005. Riparian roots through time, space and disturbance. Plant Soil, 269, 25-272.

Lovett S. and Price P. (eds.), 2007. Principles for riparian lands management. Land and Water Australia, Canberra, $20 \mathrm{p}$.

Lowrance R., Aitier L.S., Williams R.G., Inadmar S.P. and Sheridan J.M., 2000. REMM: The Riparian Ecosystem Management Model. J. Soil Water Cons., 55, 27-36.

MA (Millennium Ecosystem Assessment)., 2003. Ecosystems and Human Well Being: Framework for evaluation. World Resources Institute, Island Press, USA, 245 p.

Maass J.M. and Cotler H., 2007. Protocolo para el manejo de ecosistemas en cuencas hidrográficas. In: Cotler H. (Comp.). El manejo integral de cuencas en México: estudios y reflexiones para orientar la política ambiental (Segunda Edición). Secretaría del Medio Ambiente y Recursos Naturales, Instituto Nacional de Ecología, México D.F. 41-58.

Maass J.M., Balvanera P., Castillo A., Daily G.C., Mooney H.A., Ehrlich P., Quesada M., Miranda A., Jaramillo V.J., García-Oliva F., Martínez-Yrizar A., Cotler H., López-Blanco J., Pérez-Jiménez A., Búrquez A., Tinoco C., Ceballos G., Barraza L., Ayala R. and Sarukhán J., 2005. Ecosystem services of tropical dry forests: insights from long-term ecological and social research on the Pacific Coast of Mexico. Ecol. Soc., 10, 17. 
Mayer P.M., Reynolds S.K. Jr., McCutchen M.D. and Canfield T.J., 2007. Meta-Analysis of Nitrogen Removal in Riparian Buffers. J. Environ. Qual., 36, 1172-1180.

McClain M., Boyer E.W., Dent C.L., Gergel S.E., Grimm N.B., Groffman P.M., Hart S.C., Harvey J.W., Johnston C.A., Mayorga E., McDowell W.H. and Pinay G., 2003. Biogeochemical Hot Spots and Hot Moments at the Interface of Terrestrial and Aquatic Ecosystems. Ecosystems, 6, 30-312.

Muhr T. and Friese S., 2004. Use's Manual for ATLAS-ti 5.0. Scientific Software Development y Research Talk Inc., Berlín, Alemania, 466 p.

Municipio de Villa Purificación., 2009. Loaded: February 24 de febrero, 2010: http://e-local.gob.mx/ work/templates/enciclo/jalisco/mpios/14068a.htm.

Naiman R.J., Décamps H. and McClain M., 2005. Riparia: Ecology, Conservation and Management of Streamside Communities. Elsevier, Academic Press, New York, 430 p.

Nassauer J.I., 1995. Culture and changing landscape structure. Landsc. Ecol., 10, 229-237.

Nassauer J.I., 1997. Cultural sustainability. Aligning aesthetics and ecology. In: Nassauer J.I. (ed.), Placing Nature, Cultural and Landscape Ecology, Island Press, Washinton, D.C., 66-83.

Nassauer J.I., and Opdam P., 2008. Design in science: extending the landscape ecology paradigm Landsc. Ecol., 23, 633-644.

Newing H., Eagle C.M., Puri R.K. and Watson C.W., 2011. Conducting Research in Conservation: Social science methods and practice. Abingdon, Oxon, Routledge, $376 \mathrm{p}$.

Nilsson C. and Svedmark M., 2002. Basic principles and ecological consequences of changing water regimes: riparian plant communities. Environ. Manag., 30, 468-480.

Nilsson C., Pizzuto J., Moglen G.E., Palmer M.A. and Stanley E.H., 2003. Ecological Forecasting and the Urbanization of Stream Ecosystems: Challenges for Economists, Hydrologists, Geomorphologists and Ecologists. Ecosystems, 6, 65-674.

O'Neill J., Holland A. and Andrew L., 2008. Environmental values. Routledge, London, 234 p.

Ortiz-Arrona C., Gerritsen P.R., Martínez Rivera L.M., Allen A. and Snoep M., 2004. Restauración de bosques ribereños en paisajes antropogénicos, en el occidente de México. Memorias del Simposium Internacional de Restauración Ecológica, Santa Clara, Cuba.

Paré L. and Fuentes T., 2007. Gobernanza ambiental y políticas públicas en Áreas Naturales Protegidas: lecciones desde Los Tuxtlas. Universidad Nacional Autónoma de México, México, 259 p.

Patton M.Q., 2001 Qualitative Research and Evaluation Methods. Sage Publications, California, USA, $127 \mathrm{p}$.

Piña P., 2007. Regionalización eco-hidrológica de la cuenca del río Cuitzmala, Jalisco, México. Tesis de Maestría. Posgrado en Ciencias Biológicas. Universidad Nacional Autónoma de México, Mexico, $83 \mathrm{p}$.

Pringle C., 2003. What is hydrologic connectivity and why is it ecologically important? Hydr. Proc., 17, 268-2689.

Qureshi M.E. and Harrison S.R., 2003. Application of the Analytic Hierarchy Process to Riparian Revegetation Policy Options. Small-scale For. Econ. Manage. Policy, 2, 441-458.

Registro Agrario Nacional - RAN-. 2010. National Agrarian Registry. Digital cartography. UTM - WGS84. 1:50,000. Federal Government, Mexico.

Ricciardi A. and Rasmussen J.B., 1999. Extinction rates of North American freshwater fauna. Cons. Biol., 13, 1220-1222.

Robson C., 1993. Real World Research. A Resource for Social Scientists and Practitioner-Researchers. Blackwell publisher, Oxford, UK, $101 \mathrm{p}$.

Roux D.J., Rogers K.H., Biggs H.C., Ashton P.J. and Sergeant A., 2006. Bridging the ScienceManagement Divide: Moving from Unidirectional Knowledge Transfer to Knowledge Interfacing and Sharing. Ecol. Soc., 11, 4-24.

Solórzano S., 2008. Percepciones sobre servicios ecosistémicos relacionados con el agua en comunidades rurales de la cuenca del río Cuitzmala, Jalisco. Tesis de Maestría. Posgrado en Ciencias Biológicas. Universidad Nacional Autónoma de México, México, 160 p.

Stanford J., 2006. Landscapes and riverscapes. In: Hauer F.R. and Lamberti G. (eds), Methods in Stream Ecology. Academic Press, Elsevier, USA, 3-21. 
Stanford J.A. and Poole C.G., 1996. A protocol for ecosystem management. Ecol. Appl., 6, 741-744.

Strauss A., 1995. Qualitative analysis for social scientist. Cambridge University Press, San Francisco, $319 \mathrm{p}$.

Sweeney B.W. and Blaine J.G., 2007. Resurrecting the In-Stream Side of Riparian Forests, J. Contemp. Water Res. Educ., 136, 17-27.

Taylor S.J. and Bogdan R., 1987. Introducción a los métodos cualitativos de investigación. Ediciones Paidós Ibérica y Editorial Paidós, Barcelona, España, 343 p.

Thorp J.H., Thoms M.C. and Delong M.D., 2006. The Riverine Ecosystem Synthesis. Towards Conceptual Cohesiveness in River, Science, Elsevier. Academic Press, USA, 232 p.

Vargas M., 1994. Sobre el concepto de percepción. Alteridades, 4, 47-53.

Warman A., 2001. El campo mexicano en el siglo XX. México, D.F. México, Fondo de Cultura Económica, México, $262 \mathrm{p}$.

Young K., 2001. A Review and Meta-Analysis of the Effects of Riparian Zone Logging on Stream Ecosystems in the Pacific Northwest, Riparian Decision Tool, Technical Report 4. 